\title{
繶 説
}

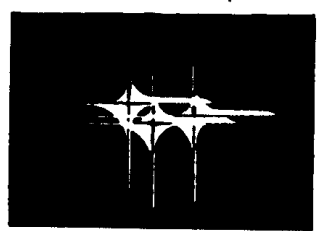

深 部体温セン サ

根

本

断熱壁

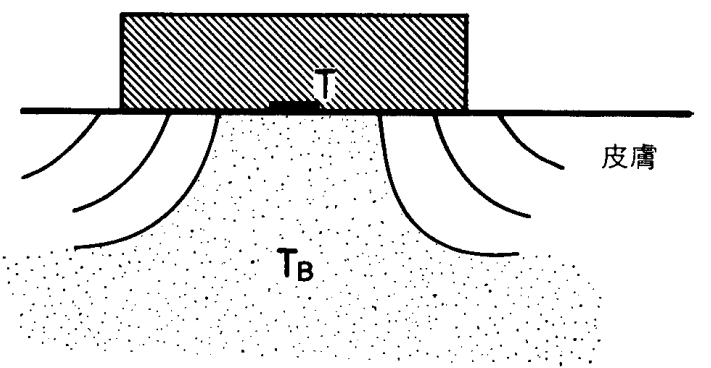

図 1 体表を断熱壁で覆ったときの組織内温度分布

(a)

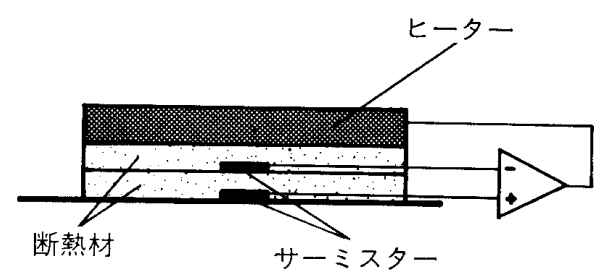

(b)

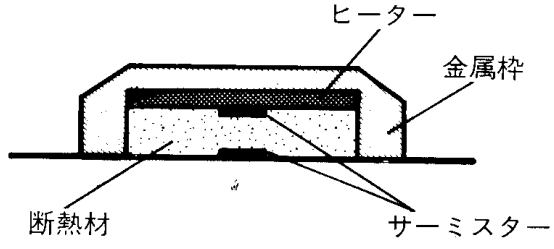

(c)

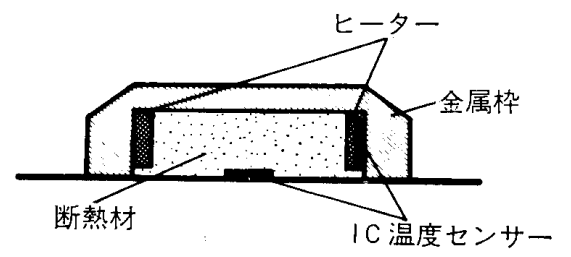

図 2 深部体温計プローブの構造

平衡状態となり等温になる。この時の体表温度 を検出することにより皮下媣部温度が計測(6)で きる。

深部体温計においては図 2 のように，体表に あてるプローブ内に 2 つの温度センサを置き， 体表温度と外側の温度を検出して, 温度差が零 になるように外側のヒータを加温する。このよ うに，プローブ外側を体表と同じ温度に保つと， 
体表から外気への熱放散が無くなり体表は媣部 組織と等温になる。

\section{2) 深部体温計プローブの構造}

墚部体温計は，体表に装着する感温部（プロ 一ブ）と, ヒータ制御および温度指示のための 電子回路からなっているが，樑部温検出特性は プローブの構造によって決定されるここで Fox らによーて開発された深部体温計のプロー ブ，市販のテルモ社製および著者らが改良した プローブ7を紹介する。

Fox らによって開発された媣部体温計のプロ ーブを2四 a に示す. 外観は $60 \times 60 \mathrm{~mm}$ ，厚 さ $5 \mathrm{~mm}$ で, 全体注シリコンゴムで被覆されて いる. プローブの体表側と外側に各 1 個のサー ミスタを内蔵させ，体表に接する温度と外側の 温度を検出寸る，ヒータはプローブ外側に置か れ，体表と外側の温度差が零になるように電流 を制御して加温を行う. 温度指示部は, $29-42$ ${ }^{\circ} \mathrm{C}$ の範囲で,メー夕直読で女る。このプローブ は温度検出セン正をプローブ中心部に置き, 温 度差が零になるように制御されているが，に一 夕温が均一でないため外周間の温度が低く, 外 周囲方向への熱流があるため断熱効果が不完全 であることがその後の研究により指摘されてい る.

現在市販されているテルモ社製深部体温計 のプローブを図 $2 \mathrm{~b}$ に示す. 直径 $80 \mathrm{~mm}$ から $45 \mathrm{~mm}, 25 \mathrm{~mm}, 15 \mathrm{~mm}$ のものがある。厚さは 直径 $45 \mathrm{~mm}$ もので $13 \mathrm{~mm}$ である。このプロ 一ブは断熱材を熱伝導性の良い金属で用むこと により，外周辺と中心部を等温に保ち，外周方 向への熱流を防ぐように改良されている。すな わち，断熱材の外枠をアルミニュウムブロック で囲い，周辺部が体表に接するようにし，プロ ーブ上面に設置したヒータがブロック全体を加 温することで，周辺温度と中心温度を等しくさ せ，周辺への熱流を零にする。温度検出にはサ 一ミスタを用いて，プローブ中心部と天井面の ヒータ温度を検出する。断熱材にウレタンフォ 一ムを用いて，その弾力によ一て，体表闻に接 する中心部のセンサ部分が，良く皮膚に密着す るような構造になっている。
図 $2 \mathrm{c}$ は, 著者らが改良した深部体温計のプ ローブの構造を示す.プローブは外枠をアルミ ニュウムブロックで作り, 内側の内壁部分に二 クロム線ヒータを側壁全面に設置した。 ヒータ 温度検出には I C 温度センサを用いている。こ のプローブの周讲壁加熱法は中心部から外周辺 への熱流を防ぐのに有効な方法である。また七 一タの温度制御回路をプローブ内に内蔵させて, 装置全体の簡略化を行った。温度センサは周囲 壁温度検出と中心部の体表面温度の2 点である が，体表涌温度検比にはセンサ 2 個を用いてヒ 一夕制御と温度指示用に分けてある。ここに用 いた I C 温度センサ(AD 590)の出力は $1 \mu \mathrm{A} / \mathrm{K}$ で絶対温度に比例する電流出力であり, 温度校 正は 1 点で行い直線化回路が不用である。電流 出力值であるため，ケーブルの抵抗による電圧 降下の影響は受けない。ヒータ制御回路は差動 増幅器とパワートランジスタで構成され，プロ ーブ内に内藏されている。ヒータ制御の調整は 周同壁温度と中心部温度が等温のときヒ一夕電 流が零となるように内蔵のポテンショメータで 行う。プローブと本体部を結ぶケーブルは電源 と温度壮力㧍よびアースの 3 本である。本体部 は電源部, 温度校正用のポテンショィータ, 差 動増幅器㧍よび表示部とから成る。

\section{3）深部温度計の温度検出特性}

図 3 にシュミレーション実験で求めた梁部 温度計の温度検出特性を示寸。シュミレーショ ン実験は $37^{\circ} \mathrm{C}$ の一定值に維持した恒温水漕内 に，底が銅で作られている箱をおう，その底に 皮下組織の代わりに，血流のない組織とほぼ等 仙什な熱伝導率を持つ厚さ 1-10 mm の合成ゴム 板を密着させる。そのゴム板表面に深部温度計 のプローブをのせ, 深部温度計が指示した樑部 温度と水槽温度との差を誤差として表した。 Fox らのプローブは外周用温度降下が大きく断 熱状態が不完全なため, 外気温の影響を受けや 寸いまたたータ温度の制御が不安定なため検 出指示温のふらつきがみられた。

市販のプローブの染部温検出能力は值径 45 $\mathrm{mm}$ の場合外気温 $25^{\circ} \mathrm{C}$ において, ت゙ム板 $6 \mathrm{~mm}$ まで士 $0.1{ }^{\circ} \mathrm{C}$ の精度で計測できるが，外気温 

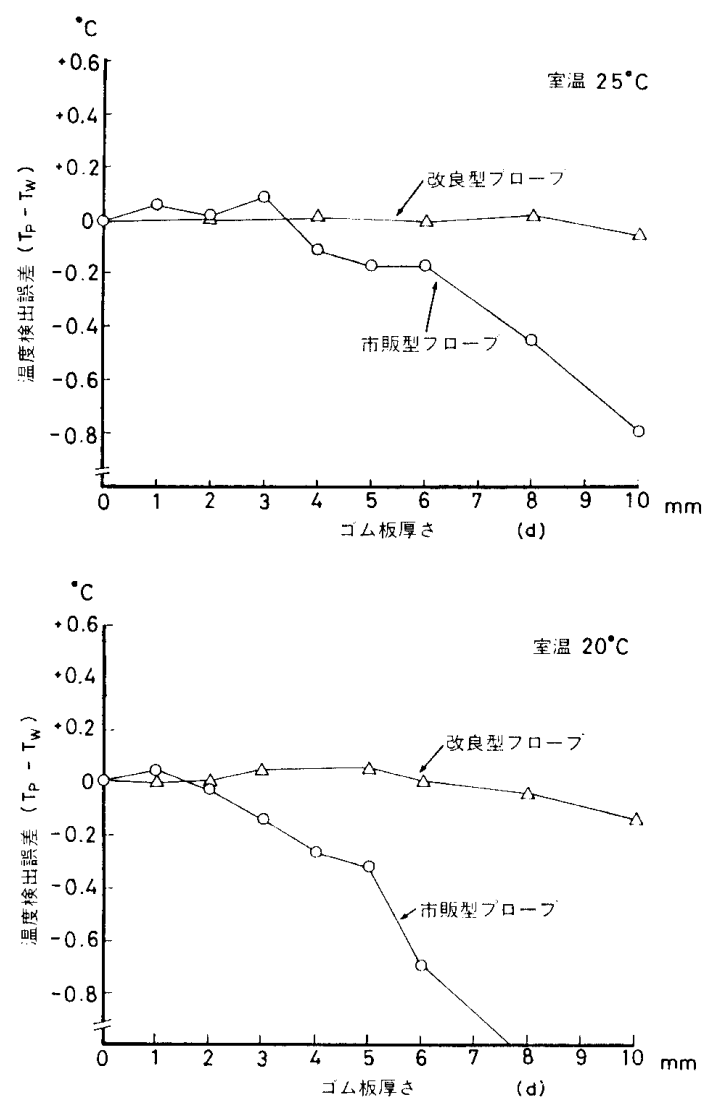

図 3 深部体温計の温度検出特性

$20^{\circ} \mathrm{C}$ では $4 \mathrm{~mm}$ までである.プローブの大き さが異なった場合の特性についての報告ももあ る.

改良型のプローブは，外周辺への熱流を防止 したことにより, 深部温検出能力特性が改善さ れている。検出精度は室温 $25^{\circ} \mathrm{C}$ の場合, ゴム 板約 $9 \mathrm{~mm}$ まで, 室温 $20^{\circ} \mathrm{C}$ で, $8 \mathrm{~mm}$ まで士 $0.1^{\circ} \mathrm{C}$ 以内で計測できる. 外気温の影響はこれ までのプローブに比べて小さく，樑部温検出能 力が向上されている。

深部温度計の応答時間についてはゴム板が 薄ければ早く平衡に達するが，ゴム板 $6 \mathrm{~mm}$ で 95\%応答に約15分要した.プローブを生体に装 着した場合, 温度が平衡に達寸るまで20分程度 を要することがある. 応答時間には, 組織の比 熱, 密度, 熱伝導率および, 体表の温度勾配の大 きい部分の厚さなどによって応答特間が異なる と考えられる.しかし，いったん平衡に達する と深部温度の変動に対して比較的速く追従する。

\section{4）生体への応用例}

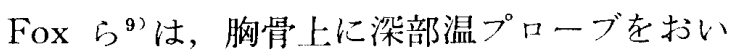

た侍の指示温度と, 外耳道温度およびラジオピ ルによって測られた消化器管内の温度と比較し ている.怅 4 は発熱物質を静脈注入して人為的 に発熱させた時の記録例である。各計測值が良 く一致している.

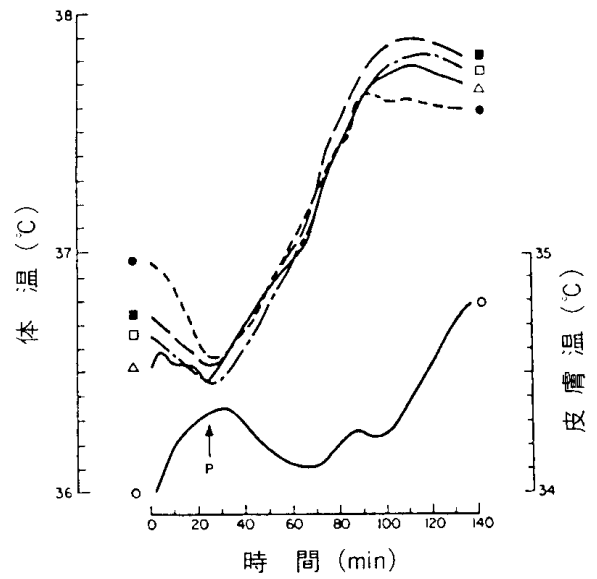

図 4 発熱物質により人為的に発熱させたときの 体温の記録

$\triangle$ 胸骨上深部体温計プローブ， $\square$ 左外耳 道温, ロ不外耳道温, ラジオビルによ る消化器内温, ○皮膚温（文献 11 より転 军)

図 5 は健常被験者の前額部, 腹部, 手掌, 足 底の 4 点にプローブを装着した時の連続記録し た 1 例である。恒温恒湿室内におてい，室温 $20^{\circ} \mathrm{C}$ ，湿度60\%で座位の状態から記録を開始 した。前額部と腹部はほぼ同じ温度を示してい るが，手掌温は徐々に降下しており，足底部は 安静の座位の状態で温度が急に降下している。

室温を $25^{\circ} \mathrm{C}$ にビると, 前額温は約 $36.9^{\circ} \mathrm{C}$ を指示して変動が少ないが，腹部温は若干降下 している. 手掌の深部温は上昇している, 足底 温も降下が止まり安定している。

臨床灾用では，深部体温計は体温モニターと して用いられ中枢温 (前額, 後頭温) と末梢温 (手掌, 足底温)の各深部温より, 体温の経時 的変化掞よび中枢温と末梢温との差より末梢循

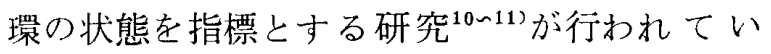
る. 従来の体温計測法との比較を表 1 に示す. この結果を見るかぎり，直腸温に比心，前額深 部温がー $0.9 \pm 0.4^{\circ} \mathrm{C}$ とかなり大きな差が認 められているが, 肺動脈血温に対しては. 前額 部温が $-0.3^{\circ} \mathrm{C} \pm 0.3^{\circ} \mathrm{C}$ と両者は良く一致し ている.このことから，前額深部温が体幹の中 


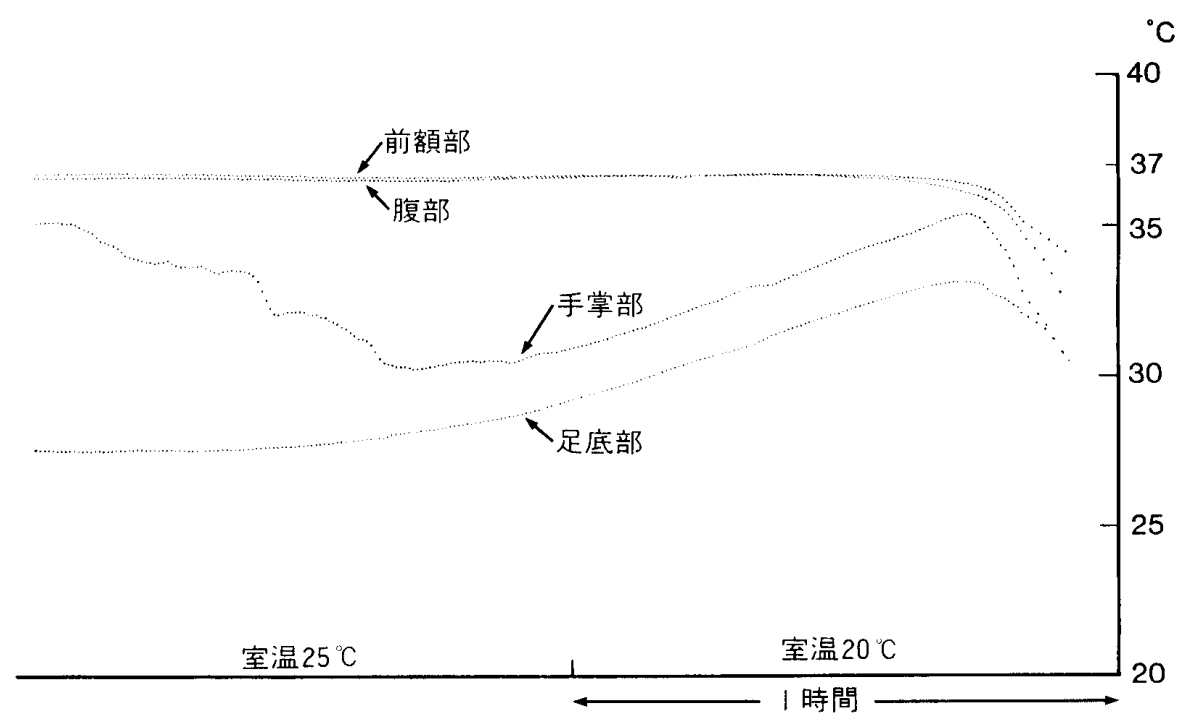

図 5 生体の前額部, 腹部, 手掌, 足底深部温の連続記録例

表 1 深部体温計と他の方法の比較

\begin{tabular}{|c|c|c|c|}
\hline $\begin{array}{l}\text { Measuring } \\
\text { site }\end{array}$ & Temperature reading & $\begin{array}{l}\text { No. of } \\
\text { cases }\end{array}$ & Refernce \\
\hline Over sternum & $\begin{array}{l}0.1^{\circ} \pm 0.4^{\circ} \mathrm{C} \text { below recta } 1 \\
\text { temperature }\end{array}$ & 15 & Ball et al. (1973) \\
\hline Occiput & $\begin{array}{l}0.1^{\circ}+0.2^{\circ} \mathrm{C} \text { below rectal } \\
\text { temperature }\end{array}$ & 15 & Togawa et al. (1976a) \\
\hline Forehead & $\begin{array}{l}0.9^{\circ} \pm 0.4^{\circ} \mathrm{C} \text { be low rectal } \\
\text { temperature }\end{array}$ & 17 & Tsuji et al. (1976) \\
\hline Forehead & $\begin{array}{l}0.3^{\circ} \pm 0.3^{\circ} \mathrm{C} \text { below rectal } \\
\text { arterial blood temperature }\end{array}$ & ${ }^{7}$ & Tsuji et al. (1976) \\
\hline Abdomen & $\begin{array}{l}0.2^{\circ} \pm 0.2^{\circ} \mathrm{C} \text { below pulmonary } \\
\text { temperarure (large probe } \\
\text { of } 100 \mathrm{~mm} \text { diameter) }\end{array}$ & 22 & Tsuji et al. (1976) \\
\hline Over biceps & $\begin{array}{c}0.14^{\circ} \pm 0.1^{\circ} \mathrm{C} \text { below muscle } \\
\text { temperature in exercise }\end{array}$ & 3 & Togawa et al. (1976b) \\
\hline
\end{tabular}

心部の温度を表し，中枢温の指標として十分信 頼できると考えられる。

\section{5）おわり}

Fox らによって最初に開発された深部体温計 は，精度的に若干問題があり，女まり普及しな かったが，その後の改良された深部温度計は臨 床に用いられ，体温モ二ターとしてその有用性 が認められている．臨床使用の結果から，前額 深部温が血液温と良く一致して，中枢温の指標 として十分信頼できるとされている.

また，使用目的によって，種々の型の深部体 温計が試みられている。電池駆動のポータブル 体温計として外枠金属を断熱材で覆いヒータ消 費電力を少なくしたプローブを用い，検出デー 夕を半導体メモリーに記憶して，マイクロコン

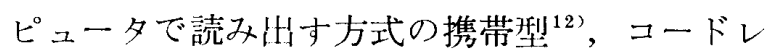
ス化をしたテレメータリング型 ${ }^{13)}$ などがある. 体外循環時, 保育器内等で使用寸るため, 体温
が環境温以下になっても計測できるように電子 冷却エレメントをプローブのヒータ部に設置 ${ }^{14}$ したもの，熱流センサを用いて，薄くフレシキ ブルにしたプローブ15)，側闻加熱方式で電子回 路を内蔵したものなどが報告されている.

樑部体温計は，体表に装着するだけで体温連 続計測を行うのに有効な方法であり，各部位の 温度を比較することにより，いろいろな生体情 報が得られることが期待できる。

\section{文献}

1) Fox, R. H. and Solman, A. J.: A new technique for monitoring the deep doby temperature in man from the intact skin surface, J. Physiol. 212, 8p (1971)

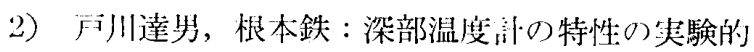
解析, 医用電子と生休厂学: 11，414 (1973)

3) Togawa, T. and Nemoto, T.: A Modified in internal temperature device, Med. Biol. Engng. 14, 36il (1976) 
4) Keetinge, W. R. and Sloan, R. E. G.: Deep body temperature from aural canal with servo-controlled heating to outer ear, J. Appl. Physiol. 38, 919, (1975)

5）芝：非接触熱電温度計，态用物理 $28 ， 422$ (1953)

6) Kobayashi, T., Nemoto, T. and Togawa, T. : lmprovement of deep body thermometer for man, Ann. Biomed. Engng. 3, 181 (1975)

7）根本鉄，过隆之，户川達男：樑部温度部プロー ブの改良，医用電子上生体工学，22，特別号， 429 (1985)

8）根本鉄，戸川達男：深部温度㖕のプローブの体 表接触面積による特性の比較, 東京医科歯科大 医用研報告 $11 ， 89$ (1977)

9) Fox R. H., Solman, A. J., Isaacs, R., Fry, A. J. and Macdonald, I. C. : A New method for monitoring deep body temperature from skin surface, Clinical Sci. 44, 81 (1973)
10）辻隆之, 須磨幸蔵, 戸川達男, 根本鉄 : 深部体 温計と心臟外科, 医用電子と生体工学, 14, 3 (1976)

11) Togawa, T., Nemoto, T., Tsuji, T. and Suma, $\mathrm{K}$ : Deep temperature monitoring in intensive care, Resuscitation 7, 53-57 (1979)

12）豊島健, 户川達男：汎用無拘束生体監視装置, その深部体温計および心拍数記録計人の店用, 東京医科歯科大医用研報告 $14 ， 27-41$ (1980)

13）池用誠, 豊島健, 根本鉄, 戸川達男：テレメ一 タリング深部体温計, 医科器械学, 48, Suppl. (1978)

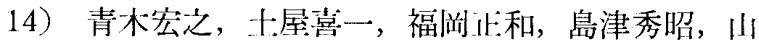
越憲一, 豊島健, 戸川達男, 伊藤寛志 : 熱流七 ンサを利用した深部体温計，医用電子と生体工 学, 22, 590-591, 特別号 (1984)

15）田村俊世, 根本鉄, 豊島健, 戸川達男：環境温 度以下の測定が川能な深部体温計, 医科器械学, 48, Suppl. (1978) 